\title{
ДОСВІД ВПРОВАДЖЕННЯ СИСТЕМИ РЕЙТИНГОВОГО ОЦІНЮВАННЯ ДІЯЛЬНОСТІ ВИКЛАДАЧІВ ТА КАФЕДР У ВИЩОМУ ДЕРЖАВНОМУ НАВЧАЛЬНОМУ ЗАКЛАДІ УКРАЇНИ “БУКОВИНСЬКИЙ ДЕРЖАВНИЙ МЕДИЧНИЙ УНІВЕРСИТЕТ”
}

\author{
Т. М. Бойчук, І. В. Геруш, В. М. Ходоровський, Є. П. Ткач \\ ВДНЗ України “Буковинський державний медичний університет”, Чернівці

\section{SYSTEM OF TEACHERS' AND DEPARTMENTS' ACTIVITIES ASSESSMENT BY RATING, IMPLEMENTATION EXPERIENCE IN THE HIGHER STATE EDUCATIONAL ESTABLISHMENT OF UKRAINE "BUKOVINIAN STATE MEDICAL UNIVERSITY"}

\author{
T. M. Boychuk, I. V. Herush, V. M. Khodorovskyi, Ye. P. Tkach \\ HSEE of Ukraine "Bukovinian State Medical University”, Chernivtsi
}

\begin{abstract}
У статті висвітлено досвід впровадження системи рейтингового оцінювання діяльності викладачів та кафедр у ВДНЗ України “Буковинський державний медичний університет” за останні три навчальні роки, визначені переваги нової електронної системи створення рейтингового звіту, можливий внесок рейтингової оцінки діяльності викладачів у формування рейтингу університету загалом.

The article covers the implementation experience of the system of teachers' and departments' activities assessment by rating in the Higher State Educational Establishment of Ukraine "Bukovinian State Medical University" over the past three academic years. The benefits of the new electronic system for drawing up a rating report, and the possible contribution of the teachers' activities assessment by rating to the formation of the overall university rating were determined.
\end{abstract}

Вступ. Відповідно до Закону України від 01.07.2014 р. № 1556-VII “Про вищу освіту”, стандартів і рекомендацій забезпечення якості в Європейському просторі вищої освіти визначені процедури і заходи системи забезпечення вищими навчальними закладами якості освітньої діяльності та якості вищої освіти (система внутрішнього забезпечення якості) [1].

Система внутрішнього забезпечення якості передбачає:

1) визначення принципів та процедур забезпечення якості вищої освіти;

2) здійснення моніторингу та періодичного перегляду освітніх програм;

3) щорічне оцінювання здобувачів вищої освіти та науково-педагогічних працівників і регулярне оприлюднення результатів таких оцінювань;

4) забезпечення підвищення кваліфікації науковопедагогічних працівників;

(c) Т. М. Бойчук, I. В. Геруш, В. М. Ходоровський, Є. П. Ткач
5) забезпечення наявності необхідних ресурсів для організації освітнього процесу;

6) забезпечення наявності інформаційних систем для ефективного управління освітнім процесом;

7) забезпечення публічності інформації про освітні програми, ступені вищої освіти та кваліфікації;

8) забезпечення ефективної системи запобігання та виявлення академічного плагіату.

Таким чином, вищі навчальні заклади повинні мати певні процедури та критерії, які б засвідчили високу кваліфікацію та достатній фаховий рівень співробітників, що здійснюють викладацьку діяльність.

Тобто у вищому навчальному закладі необхідно проводити заходи з оцінки якості науковопедагогічного персоналу не тільки при процедурі відбору та призначенні на посаду молодих викладачів, які обов'язково мають базовий рівень компетентності, але й для досвідчених викладачів, які постійно вдосконалюють фахову майстерність та 
повинні продемонструвати свої високі професійні уміння. Оцінка діяльності науково-педагогічних працівників за звітний період роботи на кафедрі може бути врахована як об’єктивний критерій при прийнятті рішення щодо продовження строкового трудового договору (контракту) чи обрання на посаду за конкурсом.

Основна частина. Забезпечення якості освітньої діяльності та якості надання освітніх послуг у ВДНЗ України “Буковинський державний медичний університет” контролюється шляхом впровадження системи менеджменту якості, що в достатній мірі технічно та ресурсно забезпечується на всіх етапах діяльності університету. У рамках внутрішнього моніторингу якості надання освітніх послуг уже третій рік поспіль здійснюється процедура щорічного рейтингового оцінювання діяльності викладачів та кафедр університету.

Процедура рейтингу та методика його розрахунку для оцінювання діяльності професорськовикладацького складу університету здійснюється відповідно до затвердженого в університеті Положення про рейтингову систему оцінювання діяльності кафедр та викладачів Вищого державного навчального закладу України “Буковинський державний медичний університет” (зі змінами та доповненнями).

Метою запровадження рейтингового оцінювання у БДМУ є:

- підвищення ефективності та результативності професійної діяльності науково-педагогічних (педагогічних) працівників;

- забезпечення прозорості та об’єктивності оцінювання діяльності кожного науково-педагогічного (педагогічного) працівника та структурних підрозділів університету;

- забезпечення здорової конкуренції, підвищення мотивації ефективності праці;

- забезпечення ефективної трансформації вищого навчального закладу до університету світового рівня;

- накопичення статистичної інформації про становлення і динаміку розвитку кафедр;

- стимулювання діяльності, спрямованої на підвищення якості освіти та на встановлення відповідності показників роботи університету вимогам Міністерства охорони здоров’я України, ліцензійним умовам та акредитаційним вимогам.

Основними завданнями рейтингового оцінювання є:
- розроблення і використання єдиних стандартизованих комплексних критеріїв для оцінювання і контролю рівня та ефективності діяльності науково-педагогічних працівників (педагогічних) і кафедр університету;

- формування управлінських кадрів і науковопедагогічного складу університету з урахуванням їх індивідуального внеску у підвищення рейтингу університету в цілому;

- вдосконалення діяльності та розвиток університету через критичний, серйозний і відвертий аналіз колективом результативності власної праці;

- активізація та стимулювання видів діяльності, які орієнтують і сприяють підвищенню рейтингу університету в цілому, та створення умов для професійного зростання усіх працівників;

- стимулювання нових напрямів наукових досліджень та вдосконалення науково-методичної основи викладацької діяльності;

- виявлення недоліків і проблемних питань у діяльності науково-педагогічних (педагогічних) працівників та кафедр;

- формування системи матеріального і морального стимулювання діяльності науково-педагогічних (педагогічних) працівників для подальшого їх заохочування.

Щорічне рейтингування здійснюється рейтинговою комісією, склад якої затверджується наказом по університету, координується співробітниками навчального, наукового, міжнародного та лікувального відділів, і визначається на підставі матеріалів, які представлені кафедрами та кожним викладачем.

Ресурсно забезпечується можливостями програми “Електронний журнал успішності”, що моніторується навчальним відділом та сектором моніторингу якості освіти й інформаційно-аналітичного забезпечення. Електронний журнал успішності - це Web-програма, розроблена на основі мови програмування PHP 5.4 та сервера бази даних MySQL 5.1. Перевагами електронної форми подання рейтингу кожним викладачем є його дистанційність, можливість подання матеріалів, що підтверджують вид та кількість виконаної роботи за звітний навчальний рік у вигляді гіперпосилання, сканкопії титульних листів підручників, посібників, монографій, статей та тез, сертифікатів, патентів, програм наукових і науково-методичних зібрань тощо. Особистий кабінет викладача програми “Електронний журнал успішності” містить вкладку “Рейтинг”, що відкрита для користування та внесення даних упродовж 
навчального року для кожного співробітника з високим ступенем захисту електронної інформації.

Електронна система рейтингування дозволяє формувати загальноуніверситетську базу даних і змінити концепцію зберігання та накопичення інформаційних матеріалів рейтингу: "Рейтинг = електронний архів інформації про діяльність = електронна база даних викладача, кафедри, університету” .

Діяльність кафедр та викладачів оцінюється за такими напрямами:

- навчально-методична робота;

- наукова діяльність;

- кадрова політика;

- міжнародне, державне та галузеве визнання, громадська, організаційна та виховна діяльність;
- лікувально-діагностична та організаційнометодична робота в лікувальних закладах.

Динаміка запровадження рейтингування в університеті позитивна з огляду на проведення “валідизації” та зіставлення його показників з рейтингами МО3 України, “ТОП 200” та оптимізації показників діяльності університету загалом.

Стабільна прикінцева мета щорічного рейтингу - встановлення недоліків, їх аналіз і спрямована корекція плану діяльності викладачів та кафедр на подальший період роботи за основними напрямками і вплив на формування покращеної рейтингової позиції університету 3-поміж інших навчальних закладів при проведенні моніторингу діяльності закладів вищої освіти Міністерством охорони здоров’я України.

Таблиця 1. Усереднені показники рейтингу діяльності викладачів БДМУ за 2012-2015 рр.

\begin{tabular}{|l|c|c|c|}
\hline \multirow{2}{*}{ Посада } & \multicolumn{3}{|c|}{ Середній рейтинговий бал } \\
\cline { 2 - 4 } & $2012-2013$ н. р. & 2013-2014 н. p. & $2014-2015$ н. p. \\
\hline Завідувач кафедри, професор & 461 & 720 & 420 \\
\hline Доцент, ст. викладач & 182 & 284 & 220 \\
\hline Асистент, викладач & 106 & 165 & 399 \\
\hline Загалом & 188 & 292 & \\
\hline
\end{tabular}

За наведеними показниками таблиці 1 визначено, що найбільшу кількість балів у рейтингу набирає когорта співробітників університету, що обіймають посади завідувачів кафедр та професорів. Найменшу кількість балів - асистенти та викладачі.
Середній рейтинговий бал у перерахунку на одного викладача університету за підсумком рейтингу щорічно зростає (від 188 балів за 2012-2013 н. р. до 399 балів за 2014-2015 н. р.).

Таблиця 2. Усереднені показники рейтингу викладачів БДМУ за напрямками діяльності

\begin{tabular}{|l|c|c|c|}
\hline \multirow{2}{*}{ Вид діяльності } & \multicolumn{3}{|c|}{ Середній рейтинговий бал } \\
\cline { 2 - 4 } & $2012-2013$ н. р. & $2013-2014$ н. р. & $2014-2015$ н. р. \\
\hline Навчально-методична робота & 61,7 & 59,6 & 107 \\
\hline Наукова діяльність & 105 & 147 & 240 \\
\hline Кадрова політика & 10,5 & 13,3 & 14 \\
\hline $\begin{array}{l}\text { Міжнародне, державне та галузеве визнання, гро- } \\
\text { мадська, організаційна та виховна діяльність }\end{array}$ & 5,6 & 8,3 & 2 \\
\hline $\begin{array}{l}\text { Лікувально-діагностична та організаційно- } \\
\text { методична робота в лікувальних закладах }\end{array}$ & 15,5 & 26,7 & 28,5 \\
\hline
\end{tabular}

Таблиця 3. Показники рейтингу викладачів БДМУ за напрямками діяльності у відсотковому співвідношенні

\begin{tabular}{|l|c|c|c|}
\hline \multicolumn{1}{|c|}{ Вид діяльності } & \multicolumn{3}{c|}{ Відсоток (\%) } \\
\cline { 2 - 4 } & $2012-2013$ н. p. & 2013-2014 н. p. & $2014-2015$ н. р. \\
\hline Навчально-методична робота & 31,1 & 23,1 & 26,8 \\
\hline Наукова діяльність & 53,0 & 57,0 & 60,1 \\
\hline Кадрова політика & 5,3 & 5,2 & 3,0 \\
\hline $\begin{array}{l}\text { Міжнародне, державне та галузеве визнання, громад- } \\
\text { ська, організаційна та виховна діяльність }\end{array}$ & 2,8 & 4,4 & 7,1 \\
\hline $\begin{array}{l}\text { Лікувально-діагностична та організаційно-методична } \\
\text { робота в лікувальних закладах }\end{array}$ & 7,8 & 10,4 & 100 \\
\hline Всього & 100 & 100 & \\
\hline
\end{tabular}


Позитивною є також динаміка зростання рейтингових балів за основними напрямками роботи впродовж 3-х років (див. табл. 2 та табл. 3). Максимальна кількість набраних балів залежно від року рейтингування визначена щодо виконання навчально-методичної роботи (23-31 \%), наукової роботи (53-60 \%) та лікувальної роботи (7,1-10,4%) науково-педагогічними працівниками університету. Напрямки “Кадрова політика”, “Міжнародне, державне та галузеве визнання”, “Громадська, організаційна та виховна діяльність” у когорті балів всього рейтингу коливаються у діапазоні 3-5,3 \% та 2,8-4,4 \% відповідно. Проте визначено значний приріст у динаміці трирічного моніторингу кількості балів за виконання навчально-методичної роботи (у 1,73 раза), наукової діяльності (у 2,3 раза), міжнародного, державного та галузевого визнання (у 2,14 раза), лікувальної діяльності (у 1,83 раза).

Зростання чисельності набраних балів викладачами відбулось за рахунок залучення всіх співробітників до формування показників рейтингу, ретельного аналізу рейтинговою комісією ваги кожного із визначених показників за напрямками рейтингу, перерозподіл ваги балів усереднені рейтингу на більш важливі та менш важливі відповідно до результатів Галузевого моніторингу діяльності вищих медичних закладів та закладів післядипломної освіти МОЗ України за останні 3 роки його проведення [2].

Це дало змогу суттєво збільшити кількість наукових і навчально-методичних публікацій та доповідей на наукових форумах за кордоном, поліпшити якість написання тестових завдань для інформаційних баз медичних ліцензійних іспитів “Крок”, збільшити кількість стажувань викладачів, студентів та молодих науковців за кордоном, збільшити кількість угод про співпрацю, які були укладені $з$ багатьма вищими навчальними закладами, у т. ч. закладами Євросоюзу, успішно готувати студентівпризерів та переможців II етапу Всеукраїнської студентської олімпіади та II Всеукраїнського конкурсу студентських наукових робіт.

Підтвердженням ефективної роботи моніторингу якості науково-педагогічного персоналу в університеті (внутрішнього контролю якості) $є$ результати Галузевого моніторингу діяльності вищих медичних (фармацевтичного) навчальних закладів та закладів післядипломної освіти МОЗ України у 2015 р. [3]. Відповідно до маркерних (колірних) характеристик інтегральних показників рейтингу візуалізовані види діяльності БДМУ, які вказують на успішність навчальної, виховної роботи, міжнародного, державного та галузевого визнання в університеті. Достатньо успішними визнано такі напрямки діяльності, як наукова, лікувальна робота, а також кадрова політика, фінансова і господарська діяльність. Співвідношення позицій у Галузевому рейтингу за напрямками діяльності серед інших навчальних закладів також підтверджують адекватність та зіставність внутрішніх індикаторних показників рейтингу БДМУ, обгрунтовуючи позитивну трирічну динаміку. Отже, позиціонування БДМУ серед інших 17 вищих навчальних закладів MO3 України визначено результатами Галузевого моніторингу МОЗ України за напрямками:

1) навчально-методична робота - 2 місце (2014 p. - 8 місце, 2013 р. - 10 місце) - що вказує на суттєвий приріст рейтингової позиції; 2) наукова діяльність - 8 місце (2014 р. - 11 місце, 2013 р. - 13 місце) - що вказує на достатній приріст рейтингової позиції; 3) кадрова політика - 7 місце (2014 р. 12 місце, 2013 р. - 16 місце) - що вказує на суттєвий приріст рейтингової позиції; 4) міжнародне, державне та галузеве визнання - 2 місце (2014 р. - 8 місце, 2013 р. - 18 місце) - що вказує на суттєвий приріст рейтингової позиції; 5) виховна робота - 4 місце (2014 р. - 3 місце, 2013 р. - 6 місце) - що вказує на незначну втрату позиції у рейтингу, проте це достатньо стабільний процесний індикатор, який дозволяє постійно знаходитись БДМУ в успішній зоні упродовж 3-х рейтингових років; 6) лікувальна робота - 5 місце (2014 р. - 5 місце, 2013 р. - 8 місце) - що вказує на достатньо стабільну позицію нашого університету посеред інших ВНЗ.

Висновки. Запровадження рейтингу діяльності викладачів та кафедр у ВДНЗ України “Буковинський державний медичний університет” є своєчасним, адекватним та відповідає стандартам i рекомендаціям щодо забезпечення якості у Європейському просторі вищої освіти. Рейтинг має стимулювальний характер для діяльності кафедр та викладачів, сприяє здоровій конкуренції, дозволяє адміністрації приймати управлінські кадрові рішення на підставі інформації рейтингу про результати діяльності співробітника. Рейтинг є ITоптимізованим та динамічним, що залишає можливість на зміни та корекцію. Рейтинг є зіставним та “валідизованим” з рейтингами МОЗ України, “ТОП 200” Україна. 


\section{Список літератури}

1. Стандарти і рекомендації щодо забезпечення якості в Європейському просторі вищої освіти. - К. : Ленвіт, 2006. - 35 с.

2. Про рейтингове оцінювання діяльності ВНЗ IV рівня акредитації та закладів ПО МОЗ України : наказ МОЗ України від 22.11.2013 р. № 1000.
3. Галузевий моніторинг діяльності вищих навчальних закладів, закладів післядипломної освіти МОЗ України за показниками діяльності у 2015 календарному році. Статистичний довідник / [укладачі: О. Павленко, С. Григоровська, Ю. П’ятницький, О. Волосовець, І. Булах, А. Горбань, І. Мельник, Ю. Фисун]. - Міністерство охорони здоров’я України, 2016. - 21 с.

Отримано 05.04.16 